\title{
CNC MEGMUNKÁLÓBERENDEZÉS KÍSÉRLETI MELEGEDÉSVIZSGÁLATA
}

\author{
Kundrát Tamás \\ fejlesztömérnök, Robert Bosch Power Tool Kft. \\ 3526 Miskolc, Robert Bosch Park 1., e-mail: kundrattamas@gmail.com \\ Szilágyi Attila \\ egyetemi docens, Miskolci Egyetem, Szerszámgépészeti és Mechatronikai Intézet, \\ Szerszámgépek Intézeti Tanszéke \\ 3515 Miskolc, Miskolc-Egyetemváros, e-mail: szilagyi.attila@uni-miskolc.hu
}

\begin{abstract}
Absztrakt
Cikkünkben egy 5-tengelyes DMU 40 megmunkálóközpont hökamerás melegedésvizsgálatát mutatjuk be [1]. Ismertetjük hökamerás eszközt, illetve a mérökört és a mérés körülményeit. A kísérleti vizsgálatot megelözte egy elméleti, végeselem-módszerrel történö vizsgálat, amihez elöállitottuk a berendezés 3D-s geometriai modelljét. A kisérleti vizsgálatot az elméleti eredmények alapján végeztük. Végül az elméleti és kísérleti eredmények is összehasonlitásra kerültek.
\end{abstract}

Kulcsszavak: hökamerás vizsgálat, megmunkálóberendezés, összevetés

\begin{abstract}
This article concerns a thermovision analysis of a DMU40 5-axis CNC milling machine [1] using a thermal camera. First the measuring instrument and the layout of the measurement are presented. Before this measurement a thermal model of the machine tool was creted, and an analysis by the means of the finite element method was conducted. After evaluating the results obtained by the simulations, we made the thermovision analysis. Finally, the measured and simulated results have been compared to each other and some conclusions about thermal analysis have been drawn.
\end{abstract}

Keywords: thermovision analysis, milling machine, comparative study

\section{Bevezetés}

A hő az energia egyik megjelenési formája, amely különböző hőmérsékletű rendszerek közötti áramlás formájában terjed. Egy megmunkálóberendezés hőforrásai lényegében energiaforrások, amelyekből hőenergia áramolhat a berendezés belsejébe. A hőenergia terjedésének három lehetséges módját tartjuk számon: hővezetés, hőátadás és hősugárzás. Hővezetés során a hőenergia a test részecskéin keresztül terjed, hőátadás során a részecskék makroszkopikus távolságon át terjesztik a hőt, míg sugárzás során a hőenergia elektromágneses energia formájában terjed.

\section{A melegedésvizsgálat előkészítése}

A pontosabb mérési eredmények miatt minden egyéb hőforrást eltávolítottunk a vizsgálatba vont berendezés környezetéből. A hőkamera és a mérési pont optimális távolságát $750 \mathrm{~mm}$-es értékre állítottuk be. Noha megmunkálás közben általában hütő-kenő folyadék használata is ajánlott, esetünkben, a 
mérés során, a könnyebb detektálhatóság érdekében, eltekintettünk ennek használatától. Mivel a hőmérsékletmezőről információt adó infravörös sugárzás plexiüvegen veszteségek árán halad át, miközben jelentősen szóródik is, így vizsgálataink során a berendezés munkaterét lezáró plexiburkolatot is szabaddá tettük. Emiatt, biztonsági okokból, csak egy egyszerủ marási folyamatot vizsgáltunk. A környezeti hőmérsékletet - mérést megelőzően $-T_{a m b}=23,3{ }^{\circ} \mathrm{C}$-nak mértük. Az 1. ábra foglalja össze a méréselőkészület tevékenységeit.

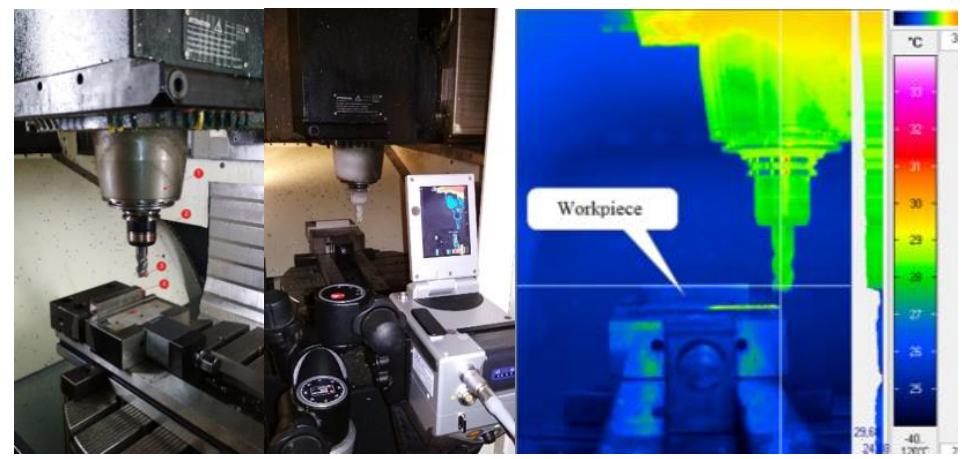

1. ábra. A vizsgálatba vont objektum kiindulási állapota.

\section{Eredmények kiértékelése}

A hökamerás méréseket követően megtörtént az eredmények értékelése, amihez az IRBIS 3 szoftvert használtuk. Elsőként a kezdeti hőmérsékleti viszonyokat tekintettük át. Ezt az 1. ábrán követhetjük nyomon, amely a forgó, de megmunkálást éppen nem végző főorsót mutatja. Egy, a szerszámon, a szerszámmegfogón, és a főorsóházon áthúzódó, viszonylag homogén hőmérsékletmező figyelhető meg.

A 2. ábra első képe már a megmunkálás közben fellépő hőmérséklet eloszlást mutatja, második képe pedig közvetlenül a megmunkálás befejezését követően készült, és ezen jól megfigyelhető a marószerszám maradó hőterhelése. Hütőközeg alkalmazását követően a felmelegedett zónák környezeti hőmérsékletre hültek. Hủtőközeg alkalmazásával a fenti folyamat gyorsabban játszódik le, óvva ezzel a marószerszámot az extrém magas hőterheléstől növelve ezzel a szerszám élettartamát.
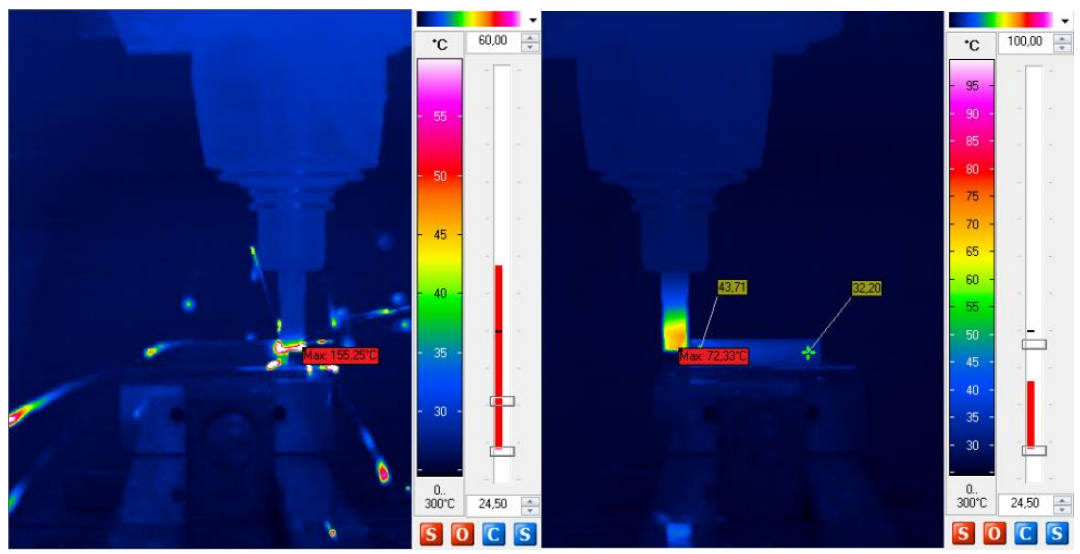

2. ábra. A megmunkálás közbeni és az azt követő hömérsékleti állapot. 


\section{Tranziens hőmérsékleti viszonyok}

Az eredmények értékelése során a folyamat tranziens részét, vagyis magát a melegedési folyamatot is vizsgáltuk. Ehhez szintén az IRBIS 3 szoftvert használtuk. Elsőként a munkadarab felület melegedési folyamatát vizsgáltuk. Ennek időbeli lefolyását a 3. ábra diagramja mutatja.

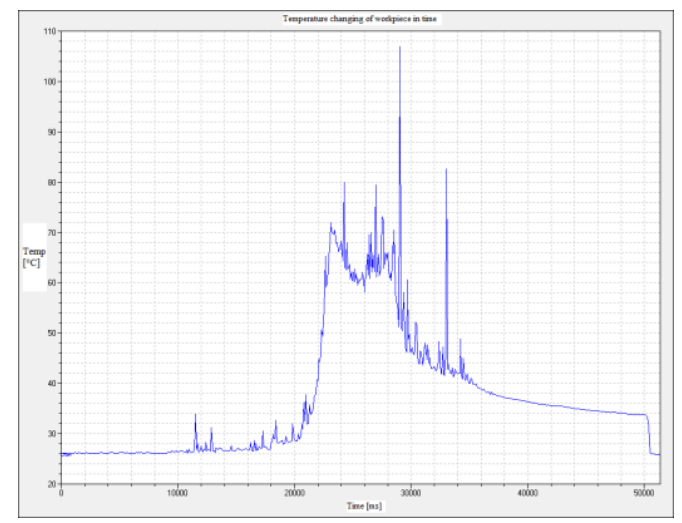

3. ábra. A munkadarab felszini hömérsékletének időbeli változása.

A vizsgált időtartomány egyes pontjaiban hőmérsékletcsúcsok figyelhetők meg, amelyek valójában a megmunkálás során keletkező, pontszerü forgácsdarabkák pillanatnyi hőmérséklete. Ezek hatását azonban kivontuk a melegedésvizsgálati eljárásból. Így, a helyi extrém hatásokat figyelmen kívül hagyó, jól illeszkedö kontrolgörbe helyezhető a felvett diagramra.

A munkadarabfelszín melegedésvizsgálata során annak hőmérséklet-maximumát is megnéztük. Megfigyelhető, hogy amint a szerszám forgácsolni kezd, felszíni hőmérséklete ugrásszerủen megemelkedik. További csúcsok is megfigyelhetők, azonban ezek, a már említett, pontszerü forgácsdarabkákhoz köthetők, és így ezek a szerszám közvetlen hőterhelésében nem játszanak szerepet. A szerszám esetén a magas hőmérséklettartományok közvetlenül a vágóélek környezetében jelennek meg, és az itt megfigyelt hőmérsékletértékek összhangban vannak a végeselem-szimuláció során nyert számítási eredményekkel. Az egyezés a fenti diagramra ráfektetett átlagológörbe és a számítási eredmények között értendő, lásd 4. ábra diagramja.

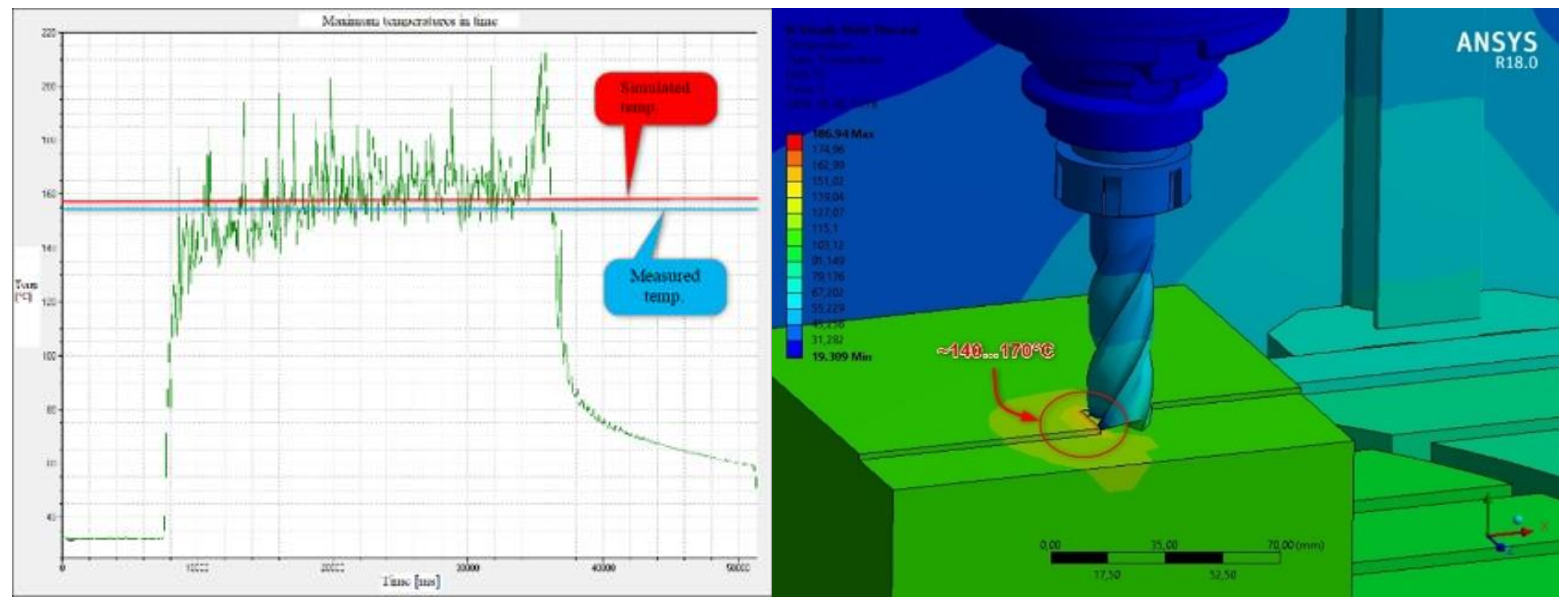

4. ábra. A mért és a számított eredmények összevetése. 
Számszerüsítve az egyezést, körülbelül $\delta \cong 2 \%$ eltérés figyelhető meg a VEM-módszerrel kapott és a kísérleti vizsgálat során nyert értékek között, amely, a struktúra összetett geometriáját, és a tranziens jelenségeket is figyelembe véve, igen kis eltérésnek számít.

A szerszám munkadarabból történő kijárásának hatása is megfigyelhető a fenti diagramon, ahol a hőmérséklet viszonylag gyors csökkenése látható. A vizsgálati időtartomány ezen szakaszán a hülési görbe az elméleti exponenciálisan csökkenő görbe alakjához igazodik, és a termikus egyensúlyi állapotot jelentő környezeti hőmérséklethez tart.

\section{5. Összefoglalás}

Cikkünkben egy 5-tengelyes fúró-maró megmunkálóberendezés melegedésvizsgálatát foglaltuk össze röviden. Bemutattuk a mérés előkészületeit, részleteztük a mérési körülményeket. Az IRBIS 3 szoftver segítségével rögzítettük a mérés eredményeit. Megállapítottuk, hogy a kísérleti vizsgálat során nyert értékek összhangban vannak a korábban elvégzett szimulációs vizsgálatok eredményeivel. A különböző módokon nyert eredmények értékei mindössze $\delta \cong 2 \%$ relatív hibával álltak elő, ami alapján kijelenthetjük, hogy a szimulációs modellünk kis hibával tükrözi a valóságot. Eredményeink alapján feltételezzük, hogy hủtőközeg esetén is hasonló korreláció figyelhető meg az elméleti és kísérleti értékek között. Fontos megemlíteni azt is, hogy mind tervezési, mind üzemeltetési fázisban fontos a mindenkori hőmérsékleti állapot ismeret, mert a hőmérséklet, illetve annak kiugró értékei jelentős mértékben befolyásolják a szerszám élettartamát, és így a munkadarab pontosságát.

\section{Köszönetnyilvánítás}

A cikkben ismertetett kutató munka az EFOP-3.6.1-16-2016-00011 jelü „Fiatalodó és Megújuló Egyetem - Innovatív Tudásváros - a Miskolci Egyetem intelligens szakosodást szolgáló intézményi fejlesztése" projekt részeként - a Széchenyi 2020 keretében - az Európai Unió támogatásával, az Európai Szociális Alap társfinanszírozásával valósul meg.

\section{Irodalom}

[1] https://en.dmgmori.com/

[2] Baráti, A.: Szerszámgép-vizsgálatok, Müszaki Könyvkiadó, Budapest, 1988. 